2 Tasker RC, Matthew DJ, Helms P, et al. Monitoring in nontraumatic coma. Part I invasive intracranial measurements. traumatic coma. Part I: invasive int

3 Tasker RC, Cole GF. Acute encephalopathy of childhood and intensive care. In: Brett EM, ed. Paediatric neurology, 3rd edn. Edinburgh: Churchill Livingstone, 1996:691-729.

4 Teasdale G, Jennett B. Assessment of coma and impaired consciousness. A practical scale. Lancet 1974;2:81-4

5 James H, Trauner D. The Glasgow Coma Scale. In: James $\mathrm{H}$, Anas N, Perkin R, eds. Brain insults in infant and children. Pathophysiology and management. Orlando: Grune and Stratton, 1985:179-82.

6 Sparrow S, Balla DA, Cicchetti DV. Vineland Adaptive Behavior Scale: interview edition, expanded form manual. Circle Pines, MN: American Guidance Service, 1984.

7 Jennett B. Epidemiology of head injury. $\mathcal{F}$ Neurol Neurosurg Psychiatr 1996;60:362-9.

8 Klauber MR, Barrett-Connor E, Marshall LF, Bowers SA The epidemiology of head injury: a prospective study of an The epidemiology of head injury: a prospective study of an Am A Epidemiol 1981;113:500-9.

9 Kraus JF, Rock A, Hemyari P. Brain injuries among infants, children, adolescents, and young adults. Am $\mathcal{F}$ Dis Child

10 Horowitz I, Costeff H, Sadan N, et al. Childhood head injuries in Israel: epidemiology and outcome. Int Rehab Med 1983;5:32-6.

11 Raimondi AJ, Hirschauer J. Head injury in the infant and toddler. Coma scoring and outcome scale. Childs Brain 1984;11:12-35.

12 Goldstein FC, Levin HS. Epidemiology of pediatric closed head injury: incidence, clinical characteristics, and risk factors. F Learn Disabil 1987;20:518-25.

13 Mazurek AJ. Epidemiology of paediatric injury. 7 Accid Emerg Med 1994;11:9-16.

14 Warren S, Moore M, Johnson MS. Traumatic head and spinal cord injuries in Alaska (1991-1993). Alaska Med 1995; 37:11-19.

15 Sosin DM, Sniezek JE, Thurman DJ. Incidence of mild and moderate brain injury in the United States, 1991. Brain Inj 1996;10:47-54.
16 Beattie TF. Minor head injury. Arch Dis Child. 1997;77: $82-5$.

17 Brendler SJ, Selverstone B. Recovery from decerebration. Brain 1970;93:381-92.

18 Bharucha PE, Bharucha EP. Coma in childhood. Indian Pediatr 1973;10:523-30.

19 Gillies JD, Seshia SS. Vegetative state following coma in childhood: evolution and outcome. Dev Med Child Neurol 1980;22:642-8.

20 Ogunmekan AO. Non-traumatic coma in childhood: etiology, clinical findings, morbidity, prognosis and mortality. F Trop Pediatr 1983;29:230-2.

21 Miller DL, Ross EM, Alderslade R, et al. Pertussis immunisation and serious acute neurological illness in children. BMF 1981;282:1595-9.

22 Seshia SS, Johnston B, Kasian G. Non-traumatic coma in childhood: clinical variables in prediction of outcome. Dev Med Child Neurol 1983;25:493-501.

23 Bates D, Caronna JJ, Cartlidge N, et al. A prospective study of nontraumatic coma: methods and results in 310 patients. Ann Neurol 1977;2:211-20.

24 Huttenlocher PR, Solitare GB, Adams G. Infantile diffuse cerebral degeneration with hepatic cirrhosis. Arch Neurol 1976;33:186-92.

25 Kraus JF, Black MA, Hessol N, et al. The incidence of acute brain injury and serious impairment in a defined population. Am f Epidemiol 1984;119:186-201.

26 Jennett B, Teasdale G, Galbraith S, et al. Severe head injuries in three countries. F Neurol Neurosurg Psychiatr 1977;40:291-8.

27 Jennett B, MacMillan R. Epidemiology of head injury. BMF 1981;282:101-4.

28 Cooper K, Tabaddor K, Hauser W, et al. The epidemiology of head injury in the Bronx. Neuroepidemiology 1983;2:7088

29 Jagger J, Levine J, Jane J, Remel R. Epidemiologic features of head injury in a predominantly rural population. $\mathcal{F}$ Trauma 1984;24:40-4.

\title{
STAMPS IN PAEDIATRICS
}

\section{Oral rehydration therapy}

Gastroenteritis is one of the major causes of childhood mortality and morbidity. Oral rehydration therapy is the cornerstone of treatment and has been widely promoted throughout the world. A number of stamps have been produced to increase public awareness and improve education. The three stamps shown here illustrate various features and aspects of this form of treatment. All relate to the UNICEF Child Survival Campaign.

M K DAVIES A J MAYNE
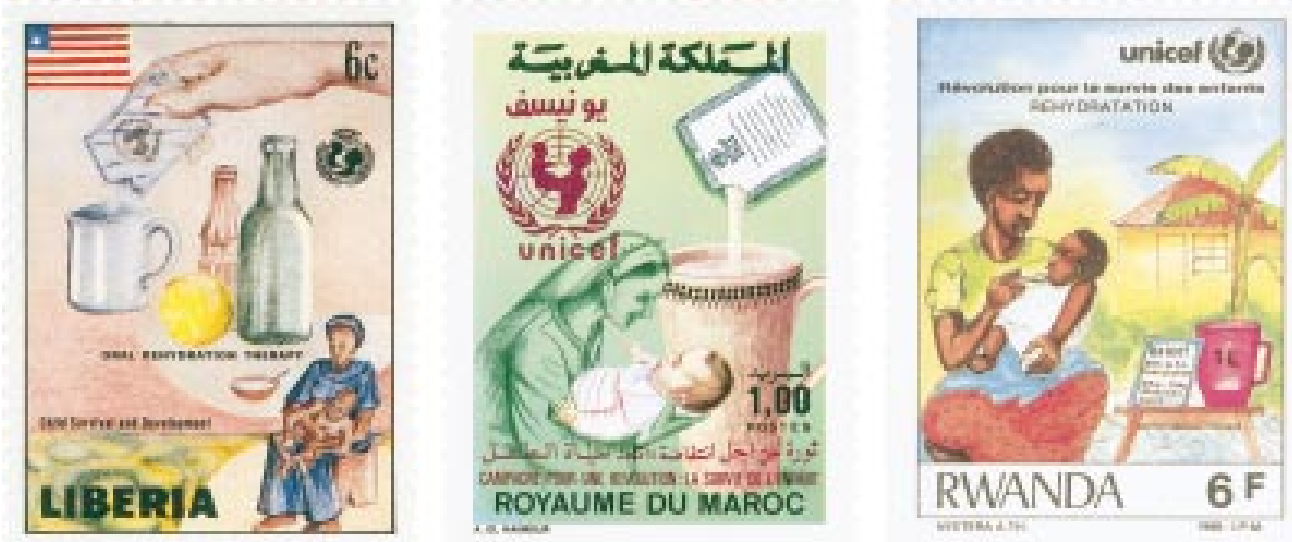